\title{
Immigrant Bodily Incorporation: How the Physical Body Affects Identity, Mobility, and Transnationalism
}

\author{
Dr. Hana Brown \\ Department of Sociology \\ Wake Forest University \\ Box 7808 \\ Winston-Salem, NC 27109 \\ (336) 758-3540 \\ brownhe@wfu.edu
}

\begin{abstract}
$\underline{\text { Abstract }}$
This article integrates insights from the sociology of the body and sociology of immigration to examine the role of the body in the immigrant incorporation process. Drawing on three years of participant observation in a West African immigrant community, I show how immigrants from a predominantly agrarian society must adapt and retrain their bodies, often under great pressure, to meet the demands of American social institutions. Immigrants' ability to move their bodies in socially prescribed ways affects three crucial aspects of the incorporation process: identity formation, economic mobility, and transnational practices. Immigrants who struggle to execute the host society's normative bodily movements (1) interpret their bodily challenges as evidence of their outsider identity, (2) struggle to acquire the material resources necessary to achieve more traditionally studied forms of economic incorporation, and (3) face limitations in their ability to maintain transnational networks even as those networks play an increasingly important social role in the face of their blocked mobility. These findings indicate that bodily incorporation is a critical precursor to full incorporation into the host society.
\end{abstract}

Keywords: immigration, incorporation, body, embodiment, refugees

\section{$\underline{\text { Acknowledgements }}$}

For their feedback on earlier drafts of this manuscript, the author thanks Kemi Balogun, Kimberly Hoang, and Jennifer Anne Meri Jones. 


\section{Immigrant Bodily Incorporation: How the Physical Body Affects Identity, Mobility, and Transnationalism}

A central question in immigration research involves the extent to which immigrants integrate into their host societies. Socioeconomic status, acculturation, and intermarriage serve as the primary indicators of incorporation (for a review see Waters and Jiménez 2005). Although researchers have occasionally noted the bodily transformations that immigrants undergo in their new countries (e.g. Choo 2006; Waters 2001; Garcia 2014), issues of the body and embodiment have taken a back seat to prevailing economic, social, and political understandings of immigrant incorporation. This gap is surprising because immigration is, at its most basic level, the movement of bodies across borders (Casanova and Jafar 2013).

Bridging scholarship on immigrant adaptation and the burgeoning literature on the sociology of the body, this article illustrates the central role of the body in the incorporation process. Because bodies are socialized to move in particular ways depending on their sociohistorical context (Bourdieu 2000), many immigrants must re-train their bodies, fashioned in one society, to interact with a wholly different institutional context. Drawing on ethnographic research in a Liberian refugee community in California, this article details the process and implications of bodily incorporation, the struggle to resocialize one's body to perform the movements required by host society institutions. For the immigrants in this study, whose bodies were socialized to thrive in a rural, agrarian society, the bodily incorporation process is prolonged and arduous. For them, physical movements that seem natural to most native-born Americans, like punching a time card, using an ATM, or dialing a telephone, require a particular type of dexterity and coordination that was not required for full membership in their society of origin. In order to access important social and economic resources in the United States, they 
must resocialize their bodies to perform specific fine motor movements that are unfamiliar to them but privileged by mainstream American institutions.

As I show below, this process of bodily adaptation has profound effects on three crucial aspects of the incorporation process: identity formation, economic mobility, and transnational practices. Immigrants who struggle to execute the host society's normative and deeply internalized bodily movements (1) interpret their bodily challenges as evidence of their outsider identity, (2) struggle to acquire the material resources necessary to achieve more traditionally studied forms of economic incorporation, and (3) face limitations in their ability to maintain transnational networks even as those networks play an increasingly important social role in the face of their blocked mobility. These findings indicate that bodily adaptation is both an important element of the incorporation process and a critical precursor to more traditionally studied forms of social and economic incorporation.

\section{Incorporation and the Body}

U.S. immigration research evaluates how similar immigrants and their children are to other Americans (Alba and Nee 1997) and examines the extent to which immigrants maintain ties to their home countries (Portes 2001). These lines of inquiry have yielded noteworthy insights about the forces that facilitate and impede immigrant adaptation. Human capital characteristics affect immigrants' incorporation, as do factors like state policies (Bloemraad 2006; Brown 2011), legal status (Portes and Zhou 1993), and encounters with race and discrimination (Massey and Sanchez 2010; Waters 2001).

Virtually all standard measures of incorporation implicate the body. Measures of socioeconomic mobility classify immigrants as either skilled or unskilled (Hagan, Lowe, and Quingla 2011), a division premised on the divide between cognitive and physical labor. 
Acquiring the host country language requires immigrants to move their bodies in new ways to produce proper vocalizations and culturally appropriate non-verbal cues. Residential patterns and intermarriage also intimately involve the body. Furthermore, as segmented assimilation research shows, immigrants' incorporation trajectories depend in part on embodied characteristics like skin color (Portes and Zhou 1993). The incorporation process thus involves a progression of projects in which the body takes center stage.

The body is a silent referent in immigration scholarship, but only a handful of studies explicitly discuss the relationship between the body and migration. These studies emphasize three themes. Research on the disciplining of immigrants' bodies examines the role of noncitizens' bodies in national discourses about fitness for legal citizenship (Molina 2006; Baynton 2001) or engages in Foucaultian analysis of bureaucrats' monitoring of immigrant bodies (Ong 2003). Scholarship on bodily labor examines employment sectors that involve intimate contact with customers bodies, emphasizing this labor as a means of negotiating status hierarchies (Lan 2003; Kang 2010). Performative studies treat bodily appearance as a form of symbolic capital for new immigrants. This research notes that immigrants alter their dress and grooming practices to symbolize belonging (Choo 2006) and transnational ties (Lowe 2013). Immigrants also alter their comportment to avoid detection by immigration officials (Garcia 2014).

These approaches suggest that the body affects immigrants' adaptation to the host society, but they also undertheorize the institutional context of incorporation and the effects of embodied practices on immigrants' life chances. To account for the stratifying effects of the body requires that researchers take seriously the fact that "the human body is socially constructed in historically changing settings of production and consumption, and by the institutions that characterize these settings" (Freund 1988, 851). Bodies are socialized to perform movements that 
meet the demands of the society in which they live, and these movements become deeply internalized and are difficult to change. Bourdieu refers to this embodied history as bodily hexis, wherein social structures become embedded in physical bodies, affecting the movements that bodies are capable of performing. Although these movements and the cognitive structures that organize them are so ingrained as to be unconscious and often unnoticed, the ability of individuals to perform these movements affects their opportunities to amass social and economic resources (Bourdieu 1984; Bourdieu 1977).

Bourdieu's empirical work illustrates the relationship between bodily hexis and social mobility. Remarking on the migration of rural French men to urban areas, Bourdieu noted that the bodies of these peasants were socialized to perform farm work, but not popular city dances (2008). Their inability to dance left them excluded from social life in towns and prompted them to view their physical bodies as evidence of their rural, agricultural nature. Bourdieu (2000) also illustrated how Algerians, whose bodies were molded in a pre-capitalist economy, struggled to adapt to the bodily demands of a capitalist system. ${ }^{1}$ In both cases, the mastery of privileged physical movements affected individuals' ability to acquire valued forms of capital.

These studies address economic change rather than international migration, but they suggest that the physical body poses a challenge for immigrant incorporation, particularly for immigrants moving between societies with different economic bases. Since institutions offer differential rewards based on specific deeply embodied physical abilities, immigrants who struggle to resocialize their bodies to meet host society demands may struggle to acquire the material resources required for full incorporation. While human capital characteristics, ascribed characteristics, and context of reception undoubtedly structure immigrant adaptation (Alba and Nee 1997; Waters and Jiménez 2005; Massey and Sanchez 2010), I argue that the physical body 
exerts its own effects on immigrant adaptation and interacts with these traditionally studied barriers to form distinct incorporation trajectories.

\section{Liberian Refugee Migration}

Data for this research come from participant-observation conducted between 2005-2007 in a Liberian immigrant community in California. From 1989 to 2003, a civil war in Liberia displaced nearly one-third of the country's population, forcing over 400,000 people into neighboring countries. Those who fled east landed in Cote d'Ivoire where a 2002 civil war erupted, targeting Liberian settlers (Coulibaly 2004). Two years later, the United Nations announced a program to resettle 7,000 of these refugees in the United States. The first wave arrived in May 2004 with additional groups arriving over the next two years. By late 2004, Liberians constituted the second largest group of recent refugees admits (ORR 2007).

Liberian refugee migration presents a useful opportunity to examine the process of bodily incorporation. If settling in a new country requires bodily resocialization, this process should pose the greatest challenge to immigrants moving from rural agrarian regions to industrialized economies. Liberian refugees possess precisely this background. Most Liberians in this refugee wave were rural subsistence farmers. Their bodies socialized to work in agrarian economies, their U.S. arrival marked the first time that most of these individuals encountered the communications, banking, and other technologies so prevalent in the United States. ${ }^{2}$ In this sense, the bodily challenges they faced were pronounced but likely similar to those of other migrants moving from agrarian to urban regions.

In addition to their rural-urban migration trajectories, these Liberian migrants offer a useful opportunity to examine bodily incorporation because they hold legal refugee status. Legal refugees are the country's most protected immigrant group. The federal government organizes 
their plane transportation to the United States. Upon arrival, they have prearranged housing, immediate and guaranteed access to an array of social programs denied to other immigrants, and a minimum of three months of job, language, and other assistance from federally-funded resettlement agencies. That the Liberian refugees in this study struggle so mightily to resocialize their bodies to American norms, even with the resettlement substantial support they receive, is testament to the value of bodily socialization in incorporation process

\section{$\underline{\text { Research Methods }}$}

To understand the incorporation process in this particular community, I began my fieldwork by working as a volunteer with the local refugee resettlement agency. For many refugees, their initial months in the United States mark the first time they have had regular access to running water and electricity. After living in rural villages, they must adapt to living in cramped urban apartments. Resettlement volunteers assist refugees with these transitions, and many refugees come to forge a strong attachment to the assigned volunteers who leverage their own familiarity with American norms and institutions to ease the resettlement process. When I began my work, I found that the simple act of identifying myself as a "volunteer" engendered a deep trust from community members. The label, along with my status as a white and welleducated American, allowed me to forge ties quickly within the community. ${ }^{3}$

As a volunteer, I tutored young children and helped families negotiate the American health, education, and social welfare systems. Their struggles to adapt their bodies to the demands of American technologies played out in each of these arenas. I worked for 18 months with various families in this community, spending on average ten hours per week in their homes and accompanying them to various appointments. I followed this informal participant- 
observation period with 12 months of formal participant observation where I closely shadowed 25 Liberian refugees and their families.

Like many refugees, the individuals I studied arrived with low levels literacy and formal education. Only two lived in urban areas of Liberia before migrating to the United States. Subsistence farmers, they immigrated to find that few of their occupational and physical skills were transferable to life in an American city. Most were single mothers whose husbands died during the conflict or grandparents left to raise their grandchildren after their own children perished during the war. ${ }^{4}$ War deaths produced a significant gender imbalance in the community and in my sample. All but four of these individuals I observed were women.

Most individuals in the community relied on government benefits and/or moved between part-time low-wage jobs. ${ }^{5}$ Only four held steady employment: one each in a hospital, nursing home, hair salon, and chain store. All of the individuals in the community spoke languages indigenous to their native communities, but conversed overwhelmingly in Liberian English . ${ }^{6}$ When I began my research, the individuals in this study had been in the United States for one to two years. Many spoke of moving back to Liberia one day and invested what income they had in rebuilding their home communities. Return was rare, however, given the unstable situation of the country and the fact that they lack formal proof of their Liberian citizenship. During the course of my research not one person managed to amass the resources necessary to return to Liberia, even for a brief visit. The imperative to adapt to life in their new country was real and persistent.

As I expanded my role from volunteer to formal participant observer, I spent increasing time in the homes of different families, both as an active participant in their day-to-day lives, engaging in informal conversations and housework, and as an observer, sitting to the side while the families went about their routines. ${ }^{7}$ I accompanied them on their trips to the bank, 
employment offices, public health clinics, grocery stores, and social welfare agencies. Because these tasks are accomplished on a daily or weekly basis I had ample opportunity to verify my findings over the course of the study period.

While in the field, I took copious field notes while completing my observations. At times, particularly during meetings at government agencies, it was not possible to take notes on site. In these cases, I wrote field notes as soon as possible afterwards. Following a grounded theory approach to coding and data analysis (Glaser and Strauss 1999), my results emerged from inductive theory building and from an ongoing dialogue with the data. This approach allowed me to generate rich descriptions and to build a theoretical framework to explain the role of the body in incorporation. I analyzed my data to trace the different contexts in which these individuals struggled to conform their bodily movements to the demands of mainstream American financial, economic, and social institutions. I also analyzed their interpretations of these struggles, tracking the financial, emotional, and other consequences of their efforts. In the following three sections, I illustrate the effects of the body on three aspects of the incorporation process: identity formation, economic mobility, and transnational practices.

\section{Identity Formation Departure and Initial Reception}

For new immigrant arrivals, adaptation to the host society involves a complex renegotiation of identity. Human capital characteristics, the timing of migration, and encounters with discriminatory policies affect whether and when immigrants eschew ethnic and national identities from the home country and self-identify with the host society (Massey and Sanchez 2010; Portes and Rumbaut 2001). Among the refugees in this study, the physical body also affected self-identification. Early in the migration process, they sensed different cultural orientations toward the body in the United States, and they experienced a double disciplining of 
their bodies, first from the state agents responsible for their incorporation and second from members of the public who found their bodily practices problematic. The body became a salient marker of their outsider status, resulting in their identification not as American but as African.

These immigrants noted the social significance of the body even before their U.S. arrival. During the refugee application process in West Africa, American immigration officials subjected them to intense medical screening, making their bodies a site of both disciplining and cultural contestation. These bodily encounters featured prominently in the refugees' recollections of the screening process. As they applied for admission to the United States, immigration officials fingerprinted them, conducted blood tests, and vaccinated them against myriad diseases. So extensive is the medical screening for refugee admission that the Centers for Disease Control (CDC) medical checklist is six pages long, single-spaced, not including the full physical and mental health exams required of new refugee admits. U.S. government officials use this medicalization of bodies to determine who is eligible for resettlement and what treatments or assistance they might require upon arrival. Any individuals with an "inadmissible health condition" (e.g. tuberculosis or syphilis) can be refused refugee status or quarantined until treated (Centers for Disease Control and Prevention 2013). It was at this moment in the migration process that many of these refugees learned that they had illnesses, most commonly venereal diseases, about which they had previously been unaware. This initial testing required further testing and further medicalization of their bodies after reaching the United States.

Perhaps because such disciplining efforts are a hallmark of state power (Scott 1999), immigrants' bodies were most subjected to them during this initial screening and arrival phase when state agents were an active presence their daily lives. State officials surveilled and tracked these refugees' bodies, but also required these individuals to monitor their own bodies in new 
ways. Mere days after these individuals arrived in the United States, refugee incorporation organizations ushered them off to doctors' appointments for additional tests and to fill prescriptions for their newly diagnosed illnesses. The early months of adjustment were marked by regular home visits by state agents whose job it was to ensure that the refugees were taking their medications on a proper schedule and monitoring their physical health and safety in expected ways.

For these refugees, the body and their own bodily practices came to represent a cultural divide between them and their host society, affecting their sense of identity. On a routine visit to the doctor's office, Rose, ${ }^{8}$ a single mother of three, lamented the American focus on bodily regulation. As we waited outside the phlebotomist's office for blood tests for her three year old son who suffered from a congenital liver defect, I asked Rose how her son would react to having his blood drawn. She replied,

Rose: He cries! They take so many vials of blood!

Author: But he is so small. He doesn't have that much blood to take.

Rose: Sometimes [the nurses] tell me that my child doesn't have much blood. I say back, 'That's because you take it all!" [She shakes her index finger.] Ah, Americans! They draw blood every day. In Africa, when they take your blood, it's because you're really sick. In America, they take your blood even if you're healthy.

Rose's cry of “Ah, Americans!" resounded through the community on a regular basis. In this instance, Rose lamented what she saw as Americans' obsession with evaluating the human body through regular blood testing. The contrast between her expectations of the physical body and 
those she encountered in the United States emphasized, to her, her status as African not American.

Rose was not the only one to interpret these bodily differences as evidence of African identity. Community members regularly expressed confusion as to why their bodies required strict monitoring when they saw little, if any, evidence of sickness. When Elizabeth, a six year old girl, was diagnosed with Hepatitis B, her extended family evidenced this very reaction. Doctors required that Elizabeth come in four times a year to have blood work done to monitor the effects of the disease on her liver. After a year, doctors told Elizabeth's mother that they wished to perform a liver biopsy, due to troubling results from her blood work. Her grandmother, the matriarch of the family, initially refused. "Why do they need to cut her body?" she asked me. “She's not sick. My girl is not sick. Look at her." Elizabeth's mother continued, "Yeah, why do they want to cut her open? They should fix this," she said, grabbing her daughter's cheeks and showing me a small rash on the child's forehead. "Americans!" she exclaimed. "They always want to cut you, take your blood, do vaccinations." For this family and other individuals in this community, this perceived over-medicalization of the body contrasted sharply with their previous lives in Liberia where preventative medical care was lacking and bodies were deemed sick only if they evidenced clear outward symptoms. Not once over the course of a medical encounter or in a discussion of medical treatment did I hear a community member self-identify as American or note feeling a sense of belonging in the United States. Rather, the routine medicalization of the body reinforced a sense of outsider status and a self-identification as "African" or "Liberian" diametrically opposed to "American."

Doctors and other bureaucrats encouraged these refugees to regulate their bodies in culturally-specific ways, but so did other Americans. In this sense, these individuals were the 
targets of a double disciplining, first from authority figures and second from the general public.

These disciplining efforts further exacerbated the community members' sense of outsider status. These experiences were most pronounced among the women. They found their bodies the subjects of greater public scrutiny than did the few men in the community. When they first arrived in the United States, the women in this community quickly noted what they perceived as American's strange views about female bodies. For example, they frequently lamented Americans' hypersensitivity to the body when it came to breastfeeding. As I sat with five women one day in a cramped living room belonging to one extended family, these Liberian mothers regaled me with stories of Americans who chided them for breastfeeding in public spaces. Martha, one of the mothers, recounted a time when she sat nursing her toddler in the waiting room of a doctor's office during one of her initial post-arrival medical appointments. "This woman," Martha explained, "she came to me, and she said 'Why do you do that so everyone can see?' I said to her, 'They're just tits. You've got them, too. Why are you making trouble?'” The story was met with a strong reaction. The others in the room shook their heads in dismay, threw their hands in the air, and issued a resounding chorus of, "Ah! Americans!" The story provided yet more evidence to them of their status as non-Americans and reaffirmed their identification with their host society.

This identity formation process bears some resemblance to "reactive ethnicity" wherein discrimination prompts immigrants to reject an American identity and self-identify with the ethnic or national group of origin (Portes and Rumbaut 2001). For the immigrants in this study, however, it was not institutional discrimination or exclusionary policies that prompted reactive ethnicity but dissonant norms about the socialized body. Although this double disciplining of the body prompted much lamentation of American social norms, it did not yield active resistance. 
These refugees understood that in order to access the institutions that would permit upward economic mobility in the United States, they had to adapt to mainstream American bodily practices. Public schools, social services agencies, and many employers required extensive medical exams and, in many cases, on-going medical supervision in order to qualify for access or benefits. Conforming to American norms about dress and nudity was also a prerequisite to finding employment. While these individuals engaged in discursive resistance to these practices, on a practical level they generally complied, understanding that active protest might jeopardize their social ties with service providers or cost them access to the institutions that provided them with necessary economic resources.

Institutional Barriers and Economic Incorporation

The imperative to resocialize their bodies affected these immigrants' sense of identity and belonging, but it also affected their economic incorporation. Economic integration is particularly crucial for immigrants because it leads to other forms of incorporation (Telles and Ortiz 2008). Factors known to influence immigrants' earnings and economic stability include legal status, skills and education, and immigration policies, but for the immigrants in this study the physical body also affected their economic status. Their bodies socialized to wield machetes and bend low to the ground to seed and harvest crops, they arrived in the United States with bodily skills that allowed them to thrive in their home villages, but they lacked the particular kind of manual dexterity required to navigate the major institutions that structured their incorporation: the state, banks, workplaces, and other bureaucracies. The inability to master these movements not only deepened their self-identification as Africans but affected their ability to obtain paid work and access other resources necessary for economic mobility. These barriers persisted despite the fact 
that they had legal authorization to work, extensive job search assistance, and the skills required to enter the American labor market.

The bodily coordination skills required to dial a telephone number are one example of the barrier the physical body posed to economic incorporation. For these immigrants, the telephone was a central means of communication with social networks back home. Without computers or internet access, the telephone was also critical to accessing mainstream American financial, medical, and other institutions. These refugees could visually recognize the numbers on a telephone, but the act of pressing the small buttons required a kind of hand-eye coordination that was not privileged in their home society. Without the proper aim or exact amount of physical pressure, their fingers would hit the wrong numbers or inadvertently enter numbers twice. These challenges were particularly pronounced for touch screen devices. Dialing a standard seven-digit telephone number could take half a dozen tries before success.

Calling social welfare agencies and banks posed a particular challenge because the refugees not only had to dial the initial number, but respond to automated response systems that required they continue to press buttons in order to reach the desired party. After multiple failed attempts to call her welfare caseworkers (an automated system that involved seven different menus in order to reach a live person), Mary, a fifty year old refugee, looked dejectedly down at her hands. "I don't know anything," she said of her inability to dial the phone. "I don't know anything," she continued. "And it makes me worry... it really makes me worry. When I have the money, I want to go back to my home. Then I won't have to worry anymore. I'll go home to Africa, I'll wake up in the morning, I'll go out to the bush, I'll do my farm work, and I won't have to worry." The routine struggle to dial a telephone produced emotional stress and dejection 
and recognition of failed incorporation into their new home. It also reinforced social identification not as American but as African.

Telephone dialing struggles also limited these individuals' ability to sustain transnational relationships and posed challenges for their economic livelihood. The individuals in this community relied on international calling cards to call West Africa, but these cards required them to use automated menus. On one occasion, I watched for 30 minutes as a family huddled in their living room and took turns trying to hit the right buttons in the proper sequence. Each individual would try three or four times to make the call, but had to start over again with every failed attempt. Ultimately, the family asked me to dial for them. Each try cost them valuable resources since they could easily lose time on the card for each attempted call, whether successful or not. Because they survived on the meager benefits provided by cash welfare and low-wage work, having calling cards "eat your money," as they put it, added to their financial stresses.

Because the telephone was also their main means of checking their bank and food stamps account balances and of contacting potential employers, their struggle to perform these movements exacerbated their financial uncertainties and complicated their job search efforts. For individuals who needed to reach welfare case workers for job search assistance or to obtain forms required for benefits continuation, the telephone was the only means of doing so. They either had to set up an appointment in advance by telephone or come into the office and use an in-house phone to call the caseworker. At least three individuals in the community saw their benefits cut or missed out on job training opportunities because they could not complete the telephone calls required to reach their caseworkers. At least two individuals missed job interview opportunities because they could not return employer phone calls to confirm or schedule a time. 
Like telephones, ATMs also proved an obstacle. Cash machines require the same type of bodily dexterity as telephones since customers must press a series of buttons to respond to automated commands. They also require that patrons hold a small, thin, rectangular card and insert it in precise fashion into a narrow slot. This feat posed a stark challenge for most of the refugees I studied. Visits to the ATM could take upwards of an hour as the immigrants endeavored to position their cards in the right direction, insert them at exactly the right angle with the precise amount of pressure, and then navigate a sea of commands to retrieve their cash.

On one trip to an ATM, I accompanied Mary and Charles, Mary's sixty year old brotherin-law, to the cash machine just a few blocks from their apartments. We approached the cash machine, and both had me stand nearby to help in the withdrawal process. Mary and Charles both had trouble inserting the card. First they tried to put it in backwards (and took a few rotations to get the card facing the right way). Then, they could not quite get the right combination of slack and pressure to get the machine to suck in the card. After ten minutes, both begged me to insert the card for them.

Determined to conquer the machine, Charles asked me to read each screen to him so he could memorize the sequence of buttons to push to complete his withdrawal. He kept repeating the pattern to himself ("number two on this side, then number one on this side, then number two on the other side..."). For Mary, I pushed enough of the buttons to get her to the point where she could enter her pin. She, like most of the refugees, had written her pin on the little paper envelope that held the EBT card she used to access her cash and food stamps benefits. Mary pulled out the business card sized envelope and held it in front of her face. She looked over at the number and looked out at the key pad on the ATM. She tentatively put her index finger up to the key pad and searched for the first number. Her muscles tensed. She could not find the right 
number to press, so after a few seconds I pointed to it. She managed to find the next three numbers but only after careful and deliberate maneuvering of her fingers. She breathed a sigh of relief when done and asked me to continue the withdrawal for her. These scenes repeated themselves month after month in the community. Although younger adults in the community acquired these bodily skills faster than their elderly counterparts, it still took them anywhere from two to three years to reach a point of comfort with the movements. The refugees' illiteracy certainly exacerbated their ATM struggles, but even when using ATMs with voice guidance systems (that read screen prompts aloud) they struggled to physically move their hands and fingers quickly, accurately, and with enough pressure to insert their cards into the machine and press the proper buttons.

Given these bodily struggles, these refugees routinely relied on volunteers and resettlement staff to help them withdraw cash. The process was stressful because it took tremendous effort and concentration to match their cards with the slots and their fingers with the buttons. It was also stressful because the ATM transactions would time out if they moved too slowly. Like other modern technologies, the ATM requires that the user be socialized to particular bodily movements but is also accompanied by "micro-penalties" of time (Foucault 1995). Using the ATM thus requires a particular type of bodily control, the absence of which is punished by a prematurely terminated transaction and the need to begin the process anew.

The economic stakes were high at each visit to the ATM. Not only could one's transaction time out, requiring a continued time investment, pushing the wrong buttons could be disastrous. They might withdraw more money than anticipated. If they did not withdraw enough money, each additional transaction cost them $\$ 2.00$ in bank fees, a hefty sum for individual subsisting on low-wage work or public benefits. One time, single mother named Grace lost 
$\$ 16.00$ to failed transactions, five percent of her monthly cash budget. Spending so long withdrawing cash from the ATM also posed safety risks as passersby watched their efforts, including their multiple attempts to enter pin numbers. Moreover, relying on others to assist in the withdrawal process made them legally vulnerable. Each time they passed their cards to another individual for assistance, they surrendered their legal rights should the card be used improperly. This was a risk not only at banks but at grocery stores where they often required help from store workers or the people behind them in line to swipe their cards to pay for food or to enter their pin numbers. While many individuals in the community were able to amass and save some capital each month, their physical struggles with financial institutions (and their lack of confidence in their ability to withdraw their money at will) made them wary of using savings accounts which would allow them to accrue interest. Instead, they kept their savings in cash under their mattresses or hidden elsewhere in their homes. Because their physical bodies effectively shut them out from the mainstream institutions that facilitated capital accumulation and economic stability, their prospects for economic incorporation remained dim.

Struggles to use the telephone and the ATM produced financial strains, but these economic stresses were exacerbated by the bodily barriers involved in job applications. After receiving a government stipend for their first months in the country, virtually all of the adult refugees in this study began applying for work. Considered "unskilled" immigrants by traditional definitions, these individuals largely sought work in local grocery stores and janitorial jobs in local stores or medical facilities. As refugees, they did not face legal barriers to employment in the United States. Not only did they have work authorization, their bodies had been socialized back home to perform the manual service jobs they sought in the United States. Legal status and 
job skill requirements not an issue, their primary barriers to finding work was the bodily requirements of the job application process.

Without computers of their own or easy access to the internet, these refugees would travel to the store to apply for positions. There, they encountered a struggle similar to dialing the phone or using an ATM: they had to use their index finger to press the proper box on a screen in order to complete their applications. This process required not only fine motor skills to which they were not socialized, it required bodily knowledge of the specific angle and force required to engage the proper toggle on the screen. Only two of the refugees navigated this process without struggle or assistance, and both had lived in urban areas in Liberia before immigrating. Thus, their bodies had already been socialized to fulfill some of the tasks that proved so challenging to others. Not surprisingly, these individuals found paid work much faster than other immigrants' in the community and were the most financially stable. Those refugees who struggled with the computerized process also struggled to find paid work, despite their ability to fulfill the requirements of the jobs they sought. For all but the urban immigrants, the physical bodily challenge of completing computerized job applications usually led them to smaller establishments where the job application process involved pen and paper or personalized networking. These jobs were typically much farther away, harder to identify, and less plentiful, leading to longer spells of unemployment and, if they found a job, fewer available working hours.

Refugee workers regularly reflected on their jobs in my presence. Their comments made clear that their bodily challenge did not end when individuals found work. The content of the manual labor they performed posed few challenges since it mirrored the work their bodies were socialized to do in their home societies. But clocking in and out of work was a different story. 
Punching time cards presented a dexterity challenge similar to the ATM. They had to hold a very slim piece of paper and insert it just right into the box in order for the timestamp to appear in the proper place. Failure to punch the timecard accurately could result in lost wages so the endeavor placed tremendous pressure on the refugee workers.

Although community members typically expressed great pride and satisfaction in their new jobs, their initial sense of elation faded when confronted with the timecard challenge. One day, while standing in her home kitchen, one of the nursing home employees confided in me the stress she faced in front of the machine each day:

You know what they make us do at work? When you come in each day, you have to take this paper." [She uses her hands to demonstrate taking your time sheet from a rack on a wall.] "Then you have to take the card. You hold it like this." [She grasps the imaginary time card with both hands.] "You turn to the machine. And you go down to the machine." [She turns her body so she's facing the microwave on the left wall of the kitchen and she bends down to about a 70 degree angle.] "Then you have to put the card in this small, small, small place." [Slowly she moves her time card to the invisible slot and puts it in.] "Then the machine goes CLING. It puts words on your card. But me, every time I do it I look down," [she looks down at her fictitious time card] "and I see I did not get the lines right. So I have to do it all again. It's hard work. It's so hard. I cannot do it right.

Her eyes filled with tears as she explained her struggles. Fearful of the consequences of incorrectly punching her time card and aware that her body was not socialized to perform the task, she would arrive at work thirty minutes early each day to ensure herself extra time to punch 
the card and often stay thirty minutes late. Added to the two hour bus ride she needed to get to her job in the first place, she would devote as much as 15 hours a day to a job that only paid her for 10. The lost time prevented her from taking on additional hours at work and from accruing much needed income.

For these individuals, each struggle with each device, whether the time card, telephone, ATM, or other technology, cost the refugees valuable time and economic resources and signaled their outsider status in their new home. Unable to perform these movements, they struggled to meet daily demands in their new homes. The time they spent negotiating these bodily movements and the stress induced by the process limited their ability to acquire other assets, manage their resources independently, and incorporate economically in a way that would facilitate upward mobility or at least a more financially stable lifestyle. The physical body affected their economic incorporation even absent the legal status and skill barriers that commonly affect immigrants' economic integration.

\section{$\underline{\text { Transnational Practices }}$}

For these individuals, the bodily movements required by mainstream American institutions reinforced their African identities, proved an obstacle to economic mobility, and limited their ability to keep regular contact with transnational networks. Yet while the struggle to dial a telephone limited the extent of transnational practices, the body also played a role in the messages these individuals sought to convey to relations back home. Economically insecure immigrants sometimes turn to transnational networks to pursue economic or social stability (Levitt and Jaworsky 2007). For the immigrants in this study, even as their bodies hindered their ability to achieve social and economic incorporation, they used their bodies to perform upward mobility to those back home and saw transforming their bodies as a key to actual incorporation. 
The most frequent example of these trends was the common practice of dressing up in fancy western clothes and having one's photograph taken by a car. Because most members of the community could not drive and did not own cars of their own, they routinely asked their nativeborn American friends, volunteers, and neighbors if they could pose by their cars for photographs. Because I typically traveled by car (a ten year old sedan) to do my field work, I regularly received such requests.

Both men and women engaged in this practice, but they used their bodies in gendered ways. Men would pose in the clothes they were wearing for the day, but women would adorn themselves in slinky dresses and costume jewelry. Everyone would pose with one arm up, leaning against the car, but men would flex their arm muscles. After these posing sessions, both men and women would send the photographs by postal mail to their networks in Liberia. About a month after one such session, Faith, a young woman in her early twenties, reminded me of the time I had taken her photograph. "Do you remember [when] you took my picture in front of your car?" she asked. I nodded. "I sent the photo to my friend in Africa. She asked me if it was my car, and I said yes." (Faith laughed.) "She told me, 'Girl look at you. You made it!"” Faith shared this story with pride, her friend's reaction offering evidence that her material acquisition marked her full membership in American society. If bodies represent modernity, globalization, and nation-building (Hoang 2014; Yuval-Davis 1997), they are also tools these immigrants used to perform their incorporation into American society both to themselves and to their networks abroad.

The body took center stage in transnational communications, but it also featured prominent in the refugees' imaginings of their futures. For Elizabeth's mother, Barbara, the body signified progress and potential incorporation. Born with a normal gait, Barbara's legs began to 
bow when she was three. By age seven, her legs were severely deformed, such that her thigh and shin bones appeared at a 45 degree angle to each other. To Barbara, her legs had long symbolized stagnation and pain. Recounting to me her family's flight from Liberia, Barbara revealed this anguish:

You know, my family - we were running in the forest... My mom had to carry me on her back like a baby, and my uncle had to carry my grandma like a baby... We would walk and then stop to sleep, and then wake up and walk some more until it was time to sleep. For one week that is what we did. And every day people were shooting at us. We would lose each other; we would hide in the river so they would not see us. My uncle did not want to carry me. He said to my mom, "What kind of child is this who cannot walk? What kind of cripple is she? ... We should leave her behind." And my mom replied, "No. We are not leaving my girl behind... If we are going to die, we are going to die together."

If Barbara's legs once symbolized conflict and stasis, they symbolized an opportunity for progress and upward mobility post-migration. At each opportunity, Barbara asked her doctors if they could repair her legs. Extensive surgery would be required, they said, but it was possible. Upon hearing the news, Barbara exploded with joy. Her reaction signaled the deep symbolism her legs held for her:

They are going to make my legs straight! I can't wait! ... I'll go back to Liberia, and I'll show everyone. I am going to wear short, short skirts." (She showed me with her hands how short the skirts would be.) ... I'm going to wear sexy, sexy skirts and sexy, sexy shorts." (Laughing) "I am going to send pictures to Africa." 
Barbara's leg project was still unfinished when I left the field, but the possibility provided hope of her eventual incorporation into her new society. Just as importantly, the promise of a new body afforded Barbara the opportunity to demonstrate her incorporation and mobility to her transnational ties.

Barbara's story is an extreme example, but others in the community also sensed that Americanized bodies would yield both incorporation in the host society and higher social status back home. For them, the ability to physically symbolize upward mobility and incorporation was important even if it did not yield these outcomes. By using their bodies to perform status attainment to social networks back home, the individuals in this study received emotional solace in the face of blocked mobility in the United States. These transnational practices demonstrate that the body is of particular symbolic importance in these immigrants' efforts to maintain social relationships across national borders, but they also underscore the fact that bodily performances alone cannot facilitate immigrant incorporation. These immigrants used their bodies to display upward mobility and incorporation, but this work did not net them tangible gains in economic mobility. Absent the bodily resocialization that would facilitate their embodied interactions with mainstream institutions, social and economic incorporation remained out of reach.

\section{Discussion and Conclusion}

This article demonstrates the centrality of the physical body in immigrants' adaptation to their host societies. I have shown that bodily adaptation affects three central aspects of the incorporation process: identity formation, economic mobility, and transnational practices. First, the disciplining efforts of American doctors and immigration officials signaled to these refugees their outsider status in the United States. Moreover, these immigrants' interpreted their inability to perform specific physical movements and gestures as a signal of their foreignness. In a process akin to reactive ethnicity (Massey and Sanchez 2010), these experiences fostered the 
development of an African or Liberian identity rather than a sense of belonging in the United States. Second, these bodily challenges affect immigrants' economic status and their ability to amass economic resources. The struggle to perform physical movements required to use ATMs, punch time cards, and dial the telephone cost these immigrants' financially, both in terms of direct costs incurred (e.g. imposed fees) and in terms of lost time. Their bodies socialized to perform other physical tasks, these immigrants found that their physical bodies effectively closed off access to many mainstream institutions like banks and jobs that could facilitate upward mobility. Not only that, these bodily struggles affected their emotional health and at times threatened their personal safety. Ultimately, these immigrants responded to their blocked mobility and perceived exclusion from the host society by using their bodies to perform mobility to their social networks back home. Such performances may have offset the emotional stresses of bodily incorporation, but did little to ameliorate the precarious social and economic position in which many of these refugees found themselves.

These findings suggest noteworthy revisions to scholarship on the body and on immigration. Existing scholarship highlights immigrants bodies as the target of disciplining (Ong 2003) and as craft-able symbols of social status (Kang 2010; Garcia 2014). In addition to its disciplining and performative aspects, the physical body also bears the imprint of the social structure in which it originated and with important implications for individuals' life chances (Bourdieu 1984). The refugees in this study did use their bodies perform social status, but these efforts reaped few rewards in terms of incorporation or upward mobility. Absent the bodily socialization required by American technologies, they struggled to complete the day-to-day financial and other tasks that would facilitate their economic mobility and they interpreted their struggles as evidence of their exclusion from American society. Rather than foster their 
incorporation, their physical bodies heightened their emotional stress, limited the time they had available to work, and even placed them at legal risk. While human capital, reception context, and ascribed characteristics certainly affect the incorporation process (Massey and Sanchez 2010; Portes and Zhou 1993), these findings suggest that incorporation also depends on adaption to the embodied practices that are normative in the receiving society. These bodily barriers may also clarify how human capital and other characteristics translate into incorporation (dis)advantages. Although the three-year time span of this study does not permit an analysis of long-term mobility prospects for these refugees, it is likely that the body will continue to pose a barrier to economic and other forms of incorporation, particularly as mainstream institutions rely increasingly on digital technologies for everyday tasks and management.

The bodily limitations on incorporation are likely to be particularly stark for immigrants like the ones in this study. From rural, agrarian societies, the contrast between their lives in Liberia and their new lives in the United States was particularly stark. Their bodies were socialized to perform tasks very different from those privileged in the United States. Both internal and international migration flows tend to move from agrarian to densely populated urban areas (Connor, Cohn, and Gonzalez-Barrera 2014), many migrants are likely to experience these bodily barriers to incorporation. It is likely that immigrants from other industrialized countries, where the technologies of mainstream institutions mirror those in the U.S., would face few, if any bodily obstacles to incorporation. Furthermore, even immigrants with higher levels of traditional human capital hailing from urban areas in countries like Liberia would likely be more socialized to the bodily movements required to maneuver adeptly through life in the United States. These findings suggest that the greater the mismatch between the home and host 
country's bodily expectations and demands, the more immigrants will struggle to incorporate socially and, particularly, economically.

The match in bodily expectations between home and host societies may help explain patterns in immigrants' mental and physical health. Immigrants in the United States and Canada typically show better health than native born citizens after arrival, an advantage that deteriorates over time, but this relationship only holds for immigrants moving between economically distinct regions of the world. That is, mental health rates remain stable for immigrants moving between countries of high economic development, but those moving from low to high development regions see a deterioration in their mental health after migration (Montazer and Wheaton 2011). My results suggest that this deterioration may result in part from the emotional and physical stresses posed by bodily incorporation, stresses likely faced most acutely by immigrants moving from low to high development regions of the world.

This article focused on the bodily incorporation of adult immigrants, but my time in the community offers suggestive evidence that the bodily barriers to adaptation may be mediated by age. The process of resocializing the body to meet American institutional demands was particularly challenging for the elderly in the community. Although most of the children were too young to provide substantive assistance to their parents and grandparents, the few children over age 10 routinely helped their adult family members dial the telephone and use card-operated machines. The relationship between age and bodily incorporation requires more extensive research, particularly on the role of the body in intergenerational immigrant relationships. Just as bilingual 1.5 and second generation children serve as translators for their adult relatives who are not proficient in English (Orellana, Dorner, and Pulido 2003), these same children likely assist in performing economic and other transactions that prove a physical challenge for the adults in their 
lives. Such obligations, like language brokering, may forge closer bonds between generations but may also heighten intergenerational conflict and affect the life chances of these youth (Foner and Dreby 2011).

Integrating a more focused study of the body into immigration research has the potential to inform the growing yet understudied field of scholarship on gender and international migration. My data come from an immigrant community that is disproportionately female, limiting my ability to draw conclusions about gender differences in bodily incorporation. That said, there is reason to believe that bodily incorporation may pose more of a barrier for immigrant women than for immigrant men. Just as gender inequality gets constructed through immigrants' bodily workplace practices (Lan 2003), gender inequalities in the sending society may yield gendered difference in bodily incorporation. Gendered economies and the gender division of labor in many migrant-sending societies may mean that women are less likely than men to arrive in the United States with exposure to the bodily practices demanded by mainstream American institutions. The liberating effects of immigration for immigrant women (HondagneuSotelo 2011; Nawyn 2010) may also be less pronounced for women who struggle to adapt their physical movements to meet the demands of mainstream American institutions. If women migrants, like those in this study, interpret their bodily struggles with time cards and ATMs as evidence of incompetence and relinquish to men control over their financial and other personal information, such results could reinforce gendered and unequal power dynamics in their families. It may also be the case that men and women struggle similarly with bodily incorporation, but that they interpret these experiences differently with divergent effects on their ultimately adaptation to American society. Future research on the bodily aspects of immigrant incorporation thus has 
the potential to inform understandings of gender inequalities and gendered relationships in the migration process.

For the immigrants in this study, the technologies used by mainstream institutions posed a particular stalwart barrier in the immigrant incorporation process. The centrality of technology raises important questions about what the rapid spread of digital technology in the developing world might portend for immigrants' incorporation. Although these developments have the potential to limit bodily obstacles to immigrant incorporation, there is ample reason to be cautious in making such claims. For one, access to digital technologies in the developing world is still limited and highly stratified. In many developing economies, fewer than $20 \%$ of all residents have access to a computer or to the internet (Pew Research Center 2015). Only 54\% of adults in developing economies have a bank account (Cohn 2015). Banking transactions in these area are completed largely through face-to-face interactions with community members rather than through computer-mediated transactions. Tellers' ability to assist customers with personal data is also far less limited by bureaucratic regulations, meaning that social relationships are likely more important than physical bodily movements in completing banking transactions. Not only are digital technologies less available in many immigrant-sending societies, the spread of new innovations happens markedly faster in most immigrant-receiving societies. For example, while $84 \%$ of residents in developing and emerging economies now have mobile phone access, only $24 \%$ of those individuals have smart phones (Pew Research Center 2015). To the extent that new technologies require different types of bodily movements, new immigrants from developing economies will still confront bodily barriers to incorporation and the body will remain a site of power and promise. 


\section{Works Cited}

Alba, Richard, and Victor Nee. 1997. "Rethinking Assimilation Theory for a New Era of Immigration.” International Migration Review 31 (4): 826-74.

Baynton, Douglas. 2001. "Disability and the Justification of Inequality in American History." In The New Disability History: American Perspectives, edited by Paul K. Longmore and Lauri Umansky, 33-57. New York, NY: NYU Press.

Bloemraad, Irene. 2006. Becoming a Citizen: Incorporating Immigrants and Refugees in the United States and Canada. Berkeley, CA: University of California Press.

Bourdieu, Pierre. 1977. Outline of a Theory of Practice. Cambridge, U.K: Cambridge University Press.

-1984. Distinction: A Social Critique of the Judgement of Taste. Cambridge, Mass.: Harvard University Press.

—. 2000. "Making the Economic Habitus Algerian Workers Revisited.” Ethnography 1 (1): 17-41.

—. 2004. "The Peasant and His Body." Ethnography 5 (4): 579-99.

—. 2008. The Bachelors' Ball: The Crisis of Peasant Society in Béarn. Chicago: University Of Chicago Press.

Brown, Hana. 2011. 'Refugees, Rights, and Race: How Legal Status Shapes Immigrants' Relationship with the State." Social Problems 58 (1): 144-63.

Casanova, Erynn Masi de, and Afshan Jafar. 2013. Bodies Without Borders. Palgrave Macmillan. Centers for Disease Control and Prevention. 2013. "Refugee Health Guidelines." Immigrant and Refugee Health. http://www.cdc.gov/immigrantrefugeehealth/guidelines/refugeeguidelines.html. 
Choo, Hae Yeon. 2006. “Gendered Modernity and Ethnicized Citizenship North Korean Settlers in Contemporary South Korea." Gender \& Society 20 (5): 576-604.

Cohn, Jonathan. 2015. “More People In The Developing World Are Getting Bank Accounts, But There's An Asterisk On That Progress.” The Huffington Post. April 15. http://www.huffingtonpost.com/2015/04/15/developing-countries-bank_n_7070824.html. Connor, Phillip, D’Vera Cohn, and Ana Gonzalez-Barrera. 2014. “Changing Patterns of Global Migration and Remittances.” Pew Research Center's Social \& Demographic Trends Project.

Coulibaly, Loucoumane. 2004. "Thousands of Liberian Refugees to Resettle in U.S." Washington Post, February 23. http://www.washingtonpost.com/wpdyn/articles/A64811-2004Feb23.html.

Doucleff, Michaeleen. 2014. “From ‘Big Jues’ To ‘Tay-Tay Water,' A Quick Guide To Liberian English." http://www.NPR.org. November 7. http://www.npr.org/sections/goatsandsoda/2014/11/07/359345125/from-big-jues-to-taytay-water-a-quick-guide-to-liberian-english.

Elias, Norbert Jephcott, Edmund, Dunning, Eric, Goudsblom, Johan. 2000. The Civilizing Process. Oxford; Malden, Mass.: Blackwell Publishers.

Foner, Nancy, and Joanna Dreby. 2011. "Relations Between the Generations in Immigrant Families." Annual Review of Sociology 37 (1): 545-64.

Foucault, Michel. 1995. Discipline and Punish: The Birth of the Prison. Vintage.

Freund, Peter E. S. 1988. "Bringing Society into the Body: Understanding Socialized Human Nature." Theory and Society 17 (6): 839-64. 
Garcia, Angela S. 2014. "Hidden in Plain Sight: How Unauthorised Migrants Strategically Assimilate in Restrictive Localities in California." Journal of Ethnic and Migration Studies 0 (0): 1-20.

Glaser, Barney, and Anselm Strauss. 1999. The Discovery of Grounded Theory: Strategies for Qualitative Research. Chicago: Aldine Transaction.

Hagan, Jacqueline, Nichola Lowe, and Christian Quingla. 2011. "Skills on the Move Rethinking the Relationship Between Human Capital and Immigrant Economic Mobility.” Work and Occupations 38 (2): 149-78.

Hoang, Kimberly. 2014. “Technologies of Embodiment: Pan-Asian Modernity and Third World Dependency in Vietnam's Contemporary Sex Industry." Gender \& Society.

Hondagneu-Sotelo, Pierrette. 2011. "Gender and Migration Scholarship: An Overview from a 21st Century Perspective." Migraciones Internacionales 6 (1): 219-33.

Kang, Miliann. 2010. The Managed Hand: Race, Gender, and the Body in Beauty Service Work. Berkeley: University of California Press.

Lan, Pei-Chia. 2003. "Working in a Neon Cage: Bodily Labor of Cosmetics Saleswomen in Taiwan." Feminist Studies 29 (1): 21-45.

Levitt, Peggy, and B. Nadya Jaworsky. 2007. "Transnational Migration Studies: Past Developments and Future Trends." Annual Review of Sociology 33 (1): 129-56. doi:10.1146/annurev.soc.33.040406.131816.

Lowe, Lucy. 2013. "Reproducing Beauty: Creating Somali Women in a Global Diaspora." In Global Beauty, Local Bodies. Palgrave Macmillan.

Massey, Douglas S., and R. Magaly Sanchez. 2010. Brokered Boundaries: Creating Immigrant Identity in Anti-Immigrant Times. Russell Sage. 
Molina, Natalia. 2006. Fit to Be Citizens? Public Health and Race in Los Angeles, 1879-1939. Berkeley: University of California Press.

Montazer, Shirin, and Blair Wheaton. 2011. "The Impact of Generation and Country of Origin on the Mental Health of Children of Immigrants." Journal of Health and Social Behavior 52 (1): $23-42$.

Nawyn, Stephanie J. 2010. "Institutional Structures of Opportunity in Refugee Resettlement: Gender, Race/Ethnicity, and Refugee NGOs." Journal of Sociology and Social Welfare 37: 149.

Office on Refugee Resettlement (ORR). 2007. "Refugee Arrival Data." www. acf.hhs.gov/programs/orr/data/refugee_annual_data.htm.

Ong, Aihwa. 2003. Buddha Is Hiding: Refugees, Citizenship, the New America. University of California Press.

Orellana, Marjorie Faulstich, Lisa Dorner, and Lucila Pulido. 2003. “Accessing Assets: Immigrant Youth's Work as Family Translators or 'Para-Phrasers.'” Social Problems 50 (4): 505-24. doi:10.1525/sp.2003.50.4.505.

Pew Research Center. 2015. "Internet Seen as Positive Influence on Education but Negative on Morality in Emerging and Developing Nations." Washignton, DC: Pew Research Center.

Portes, Alejandro. 2001. "Introduction: The Debates and Significance of Immigrant Transnationalism." Global Networks 1 (3): 181-94.

Portes, Alejandro, and Rubén G. Rumbaut. 2001. Legacies: The Story of the Immigrant Second Generation. University of California Press. 
Portes, Alejandro, and Min Zhou. 1993. "The New Second Generation: Segmented Assimilation and Its Variants." Annals of the American Academy of Political and Social Science 530: 74-96.

Scott, James C. 1999. Seeing like a State: How Certain Schemes to Improve the Human Condition Have Failed. New Haven: Yale University Press.

Telles, Edward Eric, and Vilma Ortiz. 2008. Generations of Exclusion: Mexican Americans, Assimilation, and Race. New York: Russell Sage Foundation.

Waters, Mary C. 2001. Black Identities: West Indian Immigrant Dreams and American Realities. Harvard University Press.

Waters, Mary C., and Tomás R. Jiménez. 2005. “Assessing Immigrant Assimilation: New Empirical and Theoretical Challenges." Annual Review of Sociology 31 (1): 105-25. Yuval-Davis, Nira. 1997. Gender \& Nation. London; Thousand Oaks, Calif.: Sage Publications. 


\section{$\underline{\text { Endnotes }}$}

${ }^{1}$ Elias (2000) and Foucault (1995) similarly noted that bodies are socialized and disciplined in particular ways under advanced capitalism.

${ }^{2}$ The educational and occupational background of these legal refugees differs from earlier waves of Liberian immigrants. Earlier waves had higher levels of education, more urban backgrounds, and different legal statuses. ${ }^{3}$ These refugees often used the words "volunteers" and "white people" interchangeably. Most volunteers were indeed white, but this tendency also reflected a distrust of African-Americans (Brown 2011).

${ }^{4}$ The ages provided in the manuscripts are estimates, and an exact age distribution is unavailable. Their home communities did not keep systematized records of births until relatively recently. During refugee processing, immigration agents estimated birth years for each individual and gave everyone the same date of birth: January 1 . The marital status of these individuals is similarly challenging to quantify. Three couples self-identified as married. But three additional women spoke of their husbands in West Africa. Because they lacked legal proof of marriage these men were not permitted to resettle in the United States.

${ }^{5}$ Because employment levels were so low, I did not conduct workplace observations. Data on work-related experiences come from participant-observation during the job application process and interpersonal conversations. ${ }^{6}$ Liberian English is a mixture of early pidgin English and standard English, with influences from the country's various tribal languages and from African-American settlers (Doucleff 2014).

${ }^{7}$ For most of these refugees, their experiences with formal interviews involved only tense, high-stakes, and fearinducing interviews with government officials in Liberian and Cote d'Ivoire. Because they expressed grave concerns about sitting for formal interviews, I engaged only in participant-observation rather than in-depth interviews.

${ }^{8}$ All names are pseudonyms. Any quotes with Liberian English vocabulary and grammatical structure have been translated to standard American English. 